\title{
Elite Collective Agency and the State
}

\author{
Korkut Alp Ertürk
}

Working Paper No: 2019-04

February 2019

\author{
University of Utah \\ Department of Economics \\ 260 S. Central Campus Dr., Rm. 343 \\ Tel: (801) 581-7481 \\ Fax: (801) 585-5649 \\ http://www.econ.utah.edu
}




\title{
Elite Collective Agency and the State
}

\author{
Korkut Alp Ertürk \\ University of Utah, Economics Department \\ erturk@economics.utah.edu
}

\begin{abstract}
The paper explores how elites can develop capacity for collective agency through coordination. Elites' challenge is to simultaneously deter the state from abusing power while at the same time relying on it to discipline defectors in their midst. The basic insight holds that the credibility of the state's threats depends on the cost of carrying them out, which elites can have control over if they can act in tandem. Elites can coordinate in being compliant when the ruler's threats serve their collective interest which raises the threats' credibility, while lowering that of those they dislike by their coordinated noncompliance making them costly to carry out.
\end{abstract}

Keywords: elite collective agency, state power, coordination, credible threats, subgame imperfect equilibrium

JEL Classification: C72, D72, D02 
There is a long tradition in economics that go back to Olson $(1982,1993)$ and North (1981), in which the state is modelled as a ruler who provides protection for revenue. The ruler extracts rents from its constituents as a discriminating monopolist, subject to constraints. One constraint is its potential rivals within or without society. Yet another is the ruler's own selfinterest, for extracting onerous rents or outright expropriation can lower what it can extract in the future. In addition, high extraction risks costly retaliation or yet political upheaval especially, the more a ruler is dependent on its constituents for its administrative organization. In short, countervailing economic and political power raise the ruler's cost of expropriation and extraction, constraining its ability to benefit from its coercive power.

The economic approach to political power has since spawned different strands of literature. One has embedded the maximization problem of the ruler in a more general problem of effort allocation, focusing on the welfare cost of constraining coercion and violence. Agents who are in an infinitely repeated interaction observe each other's choices, and in each period make sequential strategic decisions on how much of their effort they allocate to producing resources or building their coercive power to protect their own or raid that of others' or yet expend it on consumption or leisure that cannot be expropriated. Equilibria in which rights are respected occur under different institutional configurations (e.g., with or without a ruler), distinguished by their welfare cost measured by the deviation from the first-best allocation of effort with no coercive power. ${ }^{1}$ Another strand theorizes about the rise of democracy, focusing on elites and their interaction with the wider society. Autocracies are thought to be less constrained in violating property rights than democracies (e.g., Haber 2006, Albertus 2015, Ansell \& Samuels 2014, North 1990), and elites are thought to have greater ability to safeguard their privileges under the latter (Albertus \& Menaldo 2014, Mainwaring 1999). However, authoritarian rule might also better serve elite interests, in which case elites accept democracy only when they are forced to by non-elites. In their influential work, Acemoglu \& Robinson $(2009,2012)$ conflate elite and state power to argue that elites find it in

\footnotetext{
${ }^{1}$ See, among others, Bates et al (2002, 2008), Greif (1994b, 1998); Skaperdas (1992); Skaperdas \& Sympoulos (2002); Konrad \& Skaperdas (1996); Grossman \& Kim (1995); Moselle \& Polak (2001).
} 
their interest to concede gradual redistribution and transfer of power to non-elites when they fear the alternative can be revolution resulting in total expropriation of their wealth.

Democratic reforms arise in their view so that elites can commit to their promises of transfer of power and redistribution

A very different approach is taken by North et al. (2013) for whom democracy is the byproduct of efforts to institutionalize intra-elite coalitions based on impersonal relationships. They take issue with treating elites as well as the state as unitary actors. "Because they are not unified, elites cannot intentionally decide to do anything, let alone decide to share power" ( $p$. 149). Starting out as “...disparate groups that compete and cooperate, and sometimes go to war with each other" (p. 148), elites might create formal institutions and unify only after “...conditions allowing impersonal relations among [them] are created" (pp. 148-9). Similarly, treating the state as a single actor, they argue, "...assumes away the fundamental problem of how the state achieves a monopoly on violence", which in their view "misses how the internal dynamics of relationships among elites within the dominant coalition affect how states interact with wider society" (p. 17). They thus take as their analytical starting point dispersed power and ask how elites manage to credibility commit to stop competing through violence to form coalitions and constitute the state in the process.

The current paper discusses how elites can manage to develop capacity for collective agency. Cooperative self-restraint has little payoff for elites locked in competition for power and resources when no unified power exists to punish defectors among them. Under such conditions the equilibrium outcome is political strife. Put differently, elites find themselves in a Prisoner's Dilemma whose default outcome is non-cooperation. The paper conceptualizes possible cooperative solutions to their dilemma and examines how these can emerge. North et al (2013) place much emphasis on elites' falling coordination costs, which make their coalitions bigger in size and strength. They single out for emphasis the impact of what they call "open access systems" where elite coalitions come to depend on impersonal relationships centered on perpetually lived organizations as opposed to personal privilege and patron-client networks. The paper suggests a general framework that shows how through coordination elites can manage to develop collective agency. 
The organization of the paper is as follows. Section I suggests a conceptualization of elites and the state that draws on club theory of goods. Section II argues that elites' ability to escape their dilemma requires that they simultaneously deter the state from abusing its power while relying on it to discipline defectors in their midst. The basic insight is that the credibility of ruler's threats depends significantly on the cost of carrying them out, which elites can have control over under certain states of the world. When the ruler's threats serve their collective interest elites can coordinate in being compliant which raises the threats' credibility, while their coordinated noncompliance makes those that they dislike too costly to carry out and thus less credible. The paper ends with a brief conclusion.

\section{Elites and the State: A Club in a Club}

North (1981) traces the state's roots to communal exclusions that made possible the gradual transition from hunting/gathering to settled agriculture in early antiquity around eight to nine thousand years ago. In his view, the need to prevent resource depletion and capture the returns from investment on land required putting in place exclusions in the form of communal property rights. He writes, “... primitive agriculture, which must have been organized as exclusive common property, had the advantage over hunting in terms of the efficiency of the property rights. It is inconceivable that, from the very beginning, the first farmers did not exclude outsiders from sharing the fruits of their labors" (p. 81). ${ }^{2}$ The state emerged to enforce communal property rights, making possible drastic productivity increases in agriculture and the population spurt it supported. While North does not use the term club, his account of the emergence of the state suggests that its very essence was to transform open resources into

2 "The natural resources, whether animals to be hunted or vegetables to be gathered, were initially held as common property. This type property right implies free access to the resource by all. Economists are familiar with the proposition that unconstrained access to a resource base will lead to the depletion of the resource. The depletion can take the form, in the case of a reproducible resource, of a reduction in the biological stock below the level required for sustained yield harvesting" (North 1981, p. 80). See also Smith (1975). 
club goods through exclusion. ${ }^{3}$ Outsiders had to be excluded and insiders regulated, where both acts required an organized capacity to wield coercion (Tilly 1990), one that could be effective in safeguarding the group from outside threats and "... constraining its members with taboos, rules and, almost as effectively as if property rights had been established" (p. 81).

\begin{abstract}
Rivalrous
Non-Rivalrous
Rivalrous
Non-Rivalrous
\end{abstract}

Figure 1

\section{Exclusionary}

Non-Exclusionary

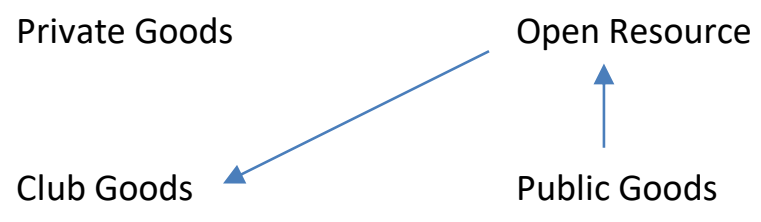

How the club is run - i.e., the way the state provides its services in assigning and enforcing property rights - is itself a good, whose type can similarly vary. For instance, in their earlier work, North \& Weingast (1989) assume an analytical structure that includes the ruler (or the ruling or dominant faction) and the people as the two main actors. The former either makes its services freely available to all (public good) or acts as a maximizing monopolist that bestows protection when that is beneficial (private good). By contrast, in their later work with John J. Wallis, the analytical topography changes with the inclusion of elites as a potential third actor

\footnotetext{
${ }^{3}$ As shown in Figure 1 public goods are non-exclusionary and non-rivalrous, while private goods are exclusionary and rivalrous. Club goods are characterized by exclusion but no rivalry (lower left) and open resources by non-exclusion and rivalry in consumption (top right). Public goods turn into common pool resources past a certain threshold of utilization as in the example of a roadway where each additional car reduces the travel time of the rest when traffic becomes congested. Consumption is then rivalrous, while no additional car going on the road faces any exclusion. Imposing some exclusion can make the roadway non-rivalrous. For instance, keeping some cars out of traffic some of the time - say, based on their license plate numbers - can transform the roadway into a club good. Alternatively, assigning private property rights would turn the roadway into a private good. See Ostrom (2003) for an in-depth conceptual history of rivalry and exclusion.
} 
(North et al 2013). The discussion here starts out from a position where power is dispersed and thus neither elites as a class nor a subset of them comprising the ruling coalition (or faction) enjoy consolidated power. In other words, neither the public nor private good configuration holds because the rule is simply the first among equals as its capacity to rule is by assumption limited. It can neither fully discriminate in whom he bestows favors, nor make its services available to all if it were so inclined. Facing off constituents powerful enough to transgress with relative impunity, its services resemble more an "over-extracted" open resource rather than some private good.

The conceptual innovation that focuses on dispersed power brings to the fore elites' collective action problem. Because they are locked in competition for power and resources, elite cohesion cannot be taken for granted. Put differently, elites face a Prisoner's Dilemma whose default outcome is mutually costly non-cooperation. Escaping their dilemma requires that they can commit to acting in cooperative self-restraint. This can potentially happen either through a durable intra-elite coalition or an all-powerful ruler who can impose order. The latter case takes us again back to protection as private good as in North \& Weingast (1989), except here open resource is its opposite rather than public good. When, alternatively, elites manage to form durable coalitions, they must have developed capacity for acting collectively, and that begs the question how.

North (1981) as discussed above traces the origins of the state to a form of "lateral" exclusion based on the territorial boundary separating us from them. Yet another form of exclusion that requires enforcement is implicit when elites are defined in terms of their exclusionary ownership of wealth and income generating assets. The social bifurcation between owners and workers, which elites' very existence normally connotes, presupposes the exclusion of the latter from the wealth monopolized by the former. Such "vertical" exclusions implied by any lopsided distribution of wealth must be self-enforced when power is dispersed, which requires elites to have own capacity to wield coercion. When elites collaborate to ward off challenges from nonelites and restrain their competition, their coalition ipso facto takes the form of an owner's club, one that is distinct from the state even when it might draw on it for 
legitimacy and organized coercive power. ${ }^{4}$ But, how do elites develop the capacity for collective agency this implies? Conflating the state with elites or treating it as an instrument of the latter might be convenient analytical shortcuts, but they beg the question. If the state is made to function as their collective organ, elites must be capable of acting collectively and that implies their rivalry is prevented from getting in the way. On the other hand, we can also ask why the state does not usurp elites' wealth by pitting one against another rather than doing their bidding.

Elites thus face two related challenges in developing capacity for collective agency: (i) disciplining defectors among their midst - and, ideally, relying on the state to do so, and (ii) deterring collectively the state from abusing its power. There is need for “... the third-party support of [their] coalition" as there must be a "credible way to discipline elites" (North et al 2013, p. 20). That is, before committing to acting in cooperative self-restraint, individual elites need a commitment device that can make them confident that others also will. Provided its threats are credible, the state can potentially function as one such commitment device. But, of course, it is not just the credibility but the nature of its threats that matter. Rephrasing North \& Weingast's (1989) well-known adage, a state that is powerful enough to deter opportunistic defection is also one that can also abuse its power. ${ }^{5}$ Dealing with this requires that elites can coordinate to project a credible collective reprisal threat against the state. ${ }^{6}$ Putting the two challenges together, the solution to elites' collective action problem as we shall see revolves around the credibility and thus the deterrence capacity of two simultaneous threats: one made by the state to deter opportunistic defection by potential elite transgressors and the other by elites to deter collectively power abuse by the state.

The problem can be stated in stylized terms. Consider the familiar dyadic Prisoner's Dilemma payoff matrix below (Figure 2) to describe unchecked intra-elite competition, where it

\footnotetext{
${ }^{4}$ North et al (2013, p. 151) argue that adjudicating disputes is a fundamental part of sustaining the elite coalition, which forms the origin of property rights and legal systems that define elite privileges. They write, "By instituting a common set of rights held by all elites, rule of law for elites, created a common interest in defending those rights" (p. 157).

${ }^{5}$ See also Weingast (1997).

${ }^{6}$ See Hardin (1995, Chp 2) on coordination and political power.
} 
is assumed that $\alpha>\beta>\theta>\delta$. Both players are better off refraining from violence and jockeying for opportunistic advantage $\left(\beta_{1}, \beta_{2}\right)$ than when neither does $\left(\theta_{1}, \theta_{2}\right)$, but Column (or Row) benefits even more if she is the only one who does not: $\delta_{1}, \alpha_{2}\left(\alpha_{1}, \delta_{2}\right)$. The Nash equilibrium, when neither self-restrain, is suboptimal for both. Mutual deterrence based on reprisal threats can be a way in which elites escape their dilemma, but that only produces a "fragile peace" (Bates 2001, p. 47) only as stable as the power balance it supports. Alternatively, they can rely on multilateral threats enforced by their coalition (and the state as its organ) to reduce the expected defection payoff. In our dyadic example, this implies that temptation payoff is reduced by a threat of sanction against defection below that of cooperation: $\alpha_{i}^{\prime}<\beta_{i}<\alpha_{i}(i=1,2)$, which transforms the Prisoner Dilemma into an Assurance game.

Elite II

Cooperate Defect

Elite I

Cooperate $\quad \beta_{1}, \beta_{2} \quad \delta_{1}, \alpha_{2}$
Defect
$\alpha_{1}, \delta_{2}$
$\theta_{1}, \theta_{2}$

Figure 2

Figures $3 \mathrm{a}$ and $3 \mathrm{~b}$ give an $\mathrm{N}$ person extension, where $\mathrm{n}$ is the number of cooperating individual elites, $\pi_{D}(n)$ the expected defection payoff and $\pi_{C}(n+1)$ is that of cooperation. In Figure $3 a$, the expected defection payoff $\pi_{D}(n)$ lies above $\pi_{C}(n+1)$ throughout, indicating that $\mathrm{n}=0$ is the only Nash equilibrium. In Figure 3b, by contrast, the expected defection payoff is lowered by a punishment threat, causing mutual restraint to become self-enforcing when $\pi_{C}(n+1)$ lies above $\pi_{D}(n)$ once the number of cooperators exceed $\mathrm{n}^{*}$. In this latter case, three Nash equilibria exist at: $n=0, n=n^{*}$ and $n=N$. Of these, the middle one is unstable and the other 
two are stable, and the expected payoff of defection is higher at any value of $n$ below $n *$ and lower at any value $n>n *$. This suggests the number of cooperators tend to diminish (increase) in the former (latter) case. Of the two possible stable Nash equilibria, mutual restraint $(n=N)$ becomes more likely the lower is the threshold value $n *$ since it then takes fewer initial cooperators before the expected cooperation payoff exceeds that of defection. It follows that the greater is the fall in their expected defection payoff $\left(\alpha^{\prime}<\alpha\right)$, the more likely elites are to escape their dilemma.

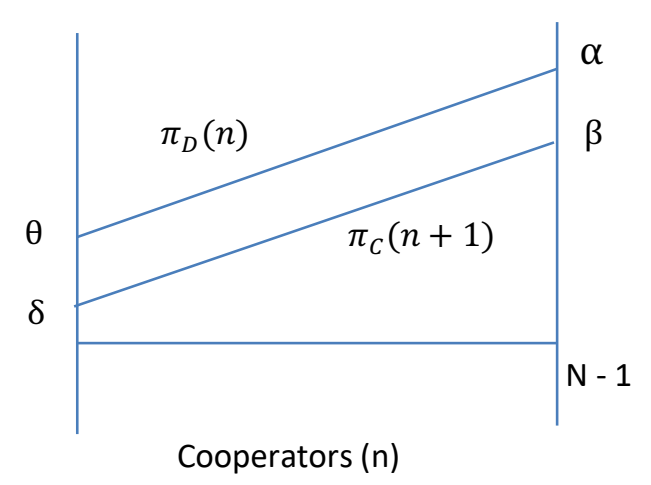

Figure $3 a$

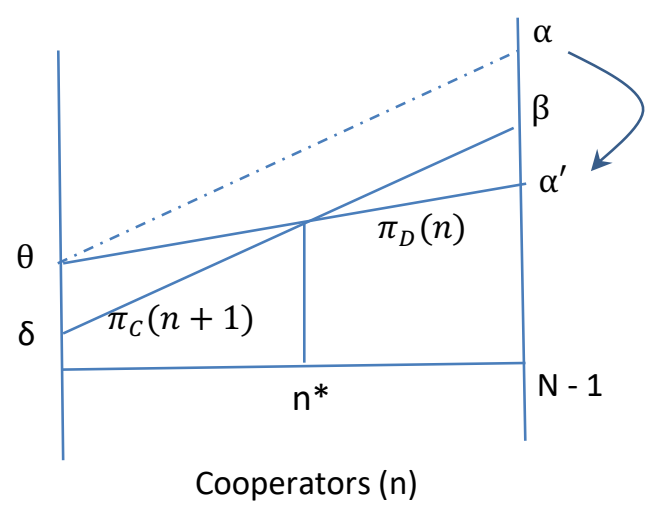

Figure $3 b$

The transition from Prisoner Dilemma (Figure 3a) into an Assurance game (Figure 3b) presupposes that elites can rely on the state to discipline potential defectors among them. But, the two questions posed earlier remain. What makes the state's threats credible and how do elites deter state abuse of power? Elites appear to face a chicken and egg problem. On the one hand, the state should not be too strong if it is to be kept in check; while, on the other, it cannot be too weak to deter defection, essential for elite reprisal threat which requires coordination. The following discusses the credibility of the ruler's threats, focusing on the cost of carrying them out, and, next, how elites through coordination can alter this cost discriminately depending on whether their interests are served by them or not. 


\section{Ruler's Threats' Credibility}

The state enforces the set of rules it imposes on its constituents by threatening sanctions against its violators. However, its threats might be less than credible if carrying them out is excessively costly. In such circumstances, the ruler might find itself better off not carrying out its threatened punishment at the subgame stage after a transgressor has ignored its threat. When potential transgressors realize this, they can then on choose not to heed its threats, since they think the ruler is better off turning a blind eye - being lax than strict - when they transgress. This makes the state's deterrence strategy sub-game equilibrium imperfect.

Consider the set of payoff combinations in sequential play in Figure 4, where the ruler $(X)$ threatens $P$ to punish a potential transgressor $(Y)$ that does $T$. If the threat succeeds in deterring $Y$, the respective payoffs remain unchanged $\left(b_{1}, b_{2}\right)$; and, when $Y$ transgresses $(T)$ anyway then $X$ must decide if it carries out the punishment $P$ it threatened. If $X$ chooses not to punish, it receives the sucker's payoff $\left(d_{1}: d_{1}<b_{1}\right)$ while $Y$ gets away with the temptation payoff $\left(a_{2}: a_{2}>b_{2}\right)$. If it does punish, both players receive their respective punishment payoffs inferior to their initial payoffs $\left(c_{1}<b_{1}, c_{2}<b_{2}\right)$. At the subgame stage after $Y$ transgressed, $X$ might not want to carry out its threatened punishment when doing so makes it worse off than turning a blind eye, i.e., if its sucker's payoff is higher than its punishment payoff $\left(d_{1}>c_{1}\right)$. X's deterrence strategy is then subgame equilibrium imperfect, which leads $\mathrm{Y}$ to ignore its threats as cheap talk, provided it believes that $\mathrm{X}$ is a rational maximizer. ${ }^{7}$

\footnotetext{
${ }^{7} \mathrm{I}$ ignore reputational costs to keep the argument simple.
} 


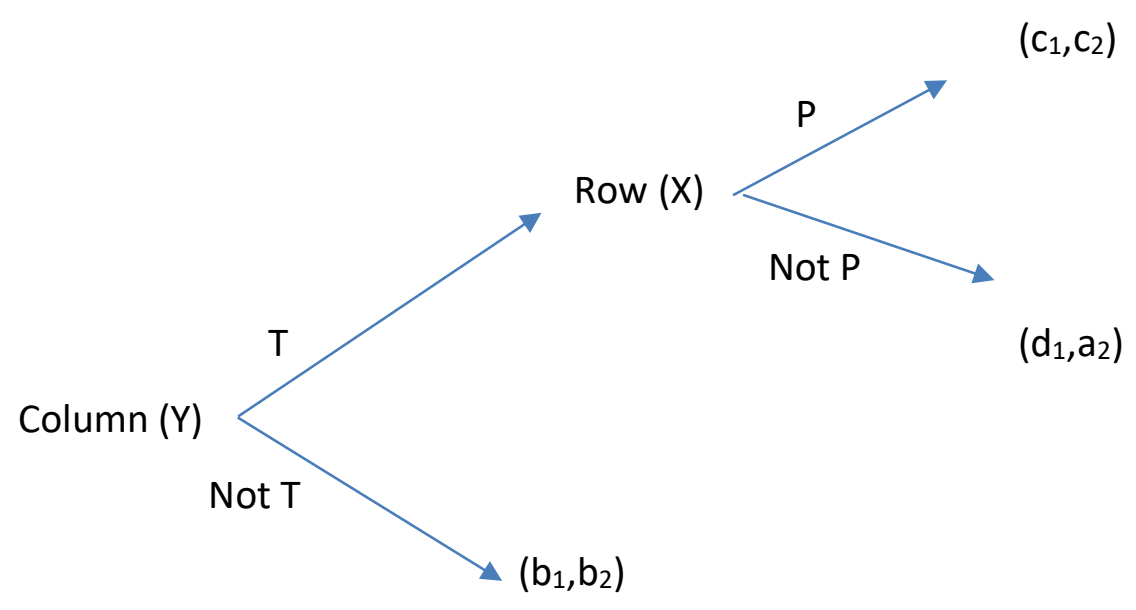

Figure 4

\section{II.1. Elite Coordination and Ruler's Threats}

The ruler's credibility problem can also be looked at from the point of view of elites. Figure 5 depicts the individual elite's expected payoffs from defiance $\left(\pi_{D}\right)$ and from compliance $\left(\pi_{C}\right)$, both as functions of the expected enforcement intensity (or probability of punishment) by the ruler. The expected defiance payoff is at its highest $\left(a_{2}\right)$ when expected enforcement is very lax (i.e., expected probability of punishment is low) and at its lowest $\left(c_{2}\right)$ when it is very strict. The ruler's threat of sanction t which it enforces with probability $\delta$, reduces the potential transgressor's expected defiance payoff to $a_{2}-\delta$ t. At some critical probability threshold, $\delta^{*}$, the two expected payoffs become equal; and, at any probability below (above) it defiance payoff is higher (lower) than that of compliance: $a_{2}-\delta t>b_{2}\left(a_{2}-\delta t<b_{2}\right)$. Thus, with a given $t$, whether a potential elite transgressor takes the ruler's threats seriously or not depends on the value he assigns to $\delta$. If it thinks $\delta$ is low (high), its compliance payoff might exceed the defiance payoff, and it is (un)likely to transgress. 


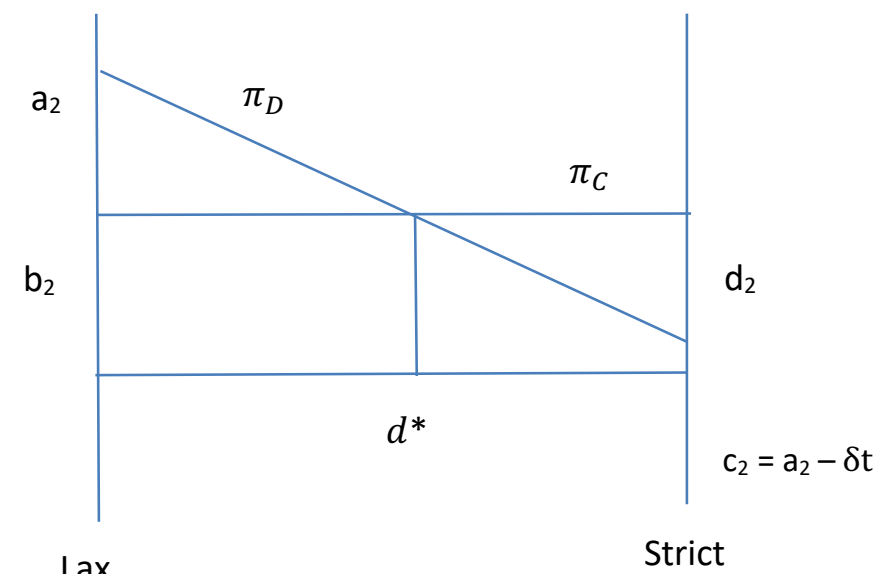

The \# of defectors (d)

Figure 5

In forming an expectation about $\delta$, the potential transgressor considers the problem from the ruler's point of view, and observes that the payoff from either strategy, being lax or strict, depends on its cost of punishment which rises with the level of defiance. The cost of being strict is higher when more elites become defiant, but so is that of being lax as well since the ruler can expect that small infractions will snowball when they are ignored early on. In other words, the ruler would expect both payoffs (from being lax and strict) to be decreasing in defiance ratio. The potential transgressor's challenge is then to assess which payoff the ruler might expect it to fall faster. If the ruler's expected payoff from being strict $\left(\pi_{S}\right)$ is likely to fall faster, the potential transgressor would assign a low value for the probability of punishment by the ruler $(\delta)$, and vice versa. Figures $6 a$ and $6 \mathrm{~b}$ depict these two possible cases. Facing increasing defiance, the ruler prefers being strict in the former and being lax in the latter. 


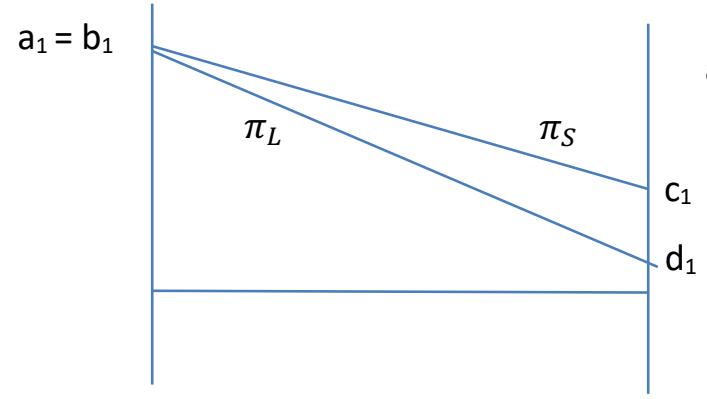

Ratio of defiance (f)

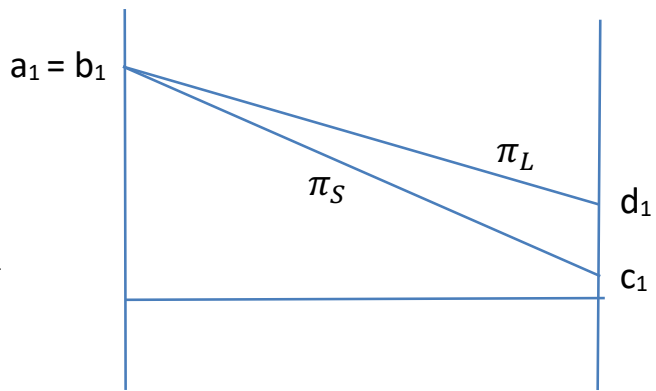

Ratio of defiance (f)

Figure 6a

Figure $6 b$

The potential transgressor would know what value to assign $\delta$ if it could tell which case is more likely. But, s/he would also need to form an expectation about what other elites will do. For if $\mathrm{s} /$ he were the only one who is defiant the ruler can punish him/her with relative ease. In other words, individual elites decide not only based on what they think about the state of the world but also on what they expect other elites will do. This is shown in Figure 7. As the number of those who assign high value for $\delta$ increases, its expected payoff rises from $E_{h}^{1}$ to $E_{h}^{2}$ at its highest, while that of assigning low value $\left(E_{L}\right)$ falls from $E_{L}^{1}$ to $E_{L}^{2}$ at its lowest. When objectively the ruler is all powerful, such that all elites expect that it would not hesitate to be strict in the face of rising defiance, the individual elites' expected payoff of assigning low value for $\delta$ even when s/he expects everyone else will also do so might still be lower than that of assigning a high value. In this case, the expected payoff of schedule $E_{L}$ lies below $E_{h}$ throughout since $E_{h}^{1}>E_{L}^{1}$ (Figure 7a), which suggests that the ruler can make credible threats and would thus have capacity to lower elites' defection payoff $\left(\alpha^{\prime}<\alpha\right)$ independently of what they do. While elites can still potentially escape their dilemma, they would only do so on ruler's terms.

In the other extreme case when power is dispersed (open resource configuration), elites remain stuck in their dilemma. They are forced to invest in own capacity to wield coercion and 
be prepared for costly open conflict whenever power balance is upset. ${ }^{8}$ The ruler here is too weak to impose discipline and potential defectors find it easy to assign low value for $\delta$. The individual elites' expected payoff of assigning high value, even when everyone else also did so, falls short of that of assigning a low value $\left(E_{L}^{2}>E_{h}^{2}\right)$, which means that the expected payoff of schedule $E_{L}$ lies above $E_{h}$ throughout (Figure $7 \mathrm{~b}$ ).

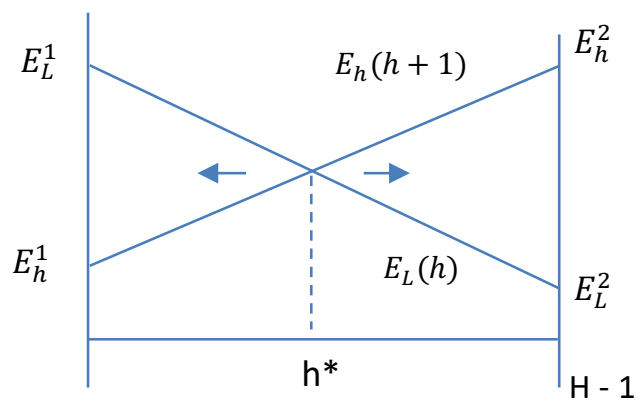

\# who assign 'high' value (h)

Figure 7

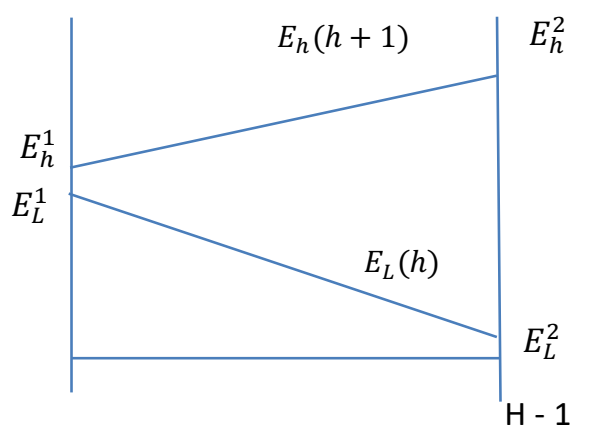

\# who assign 'high' value (h)

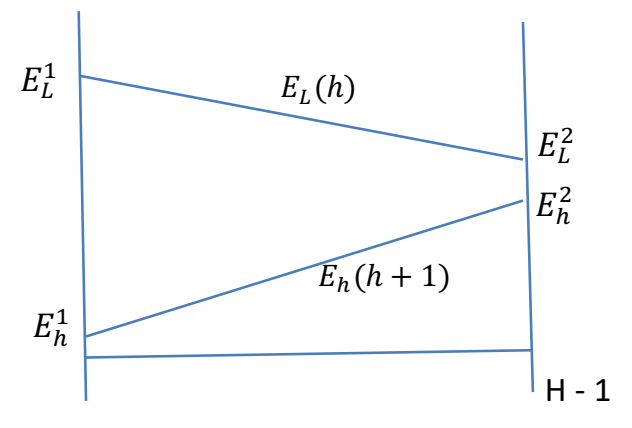

\# who assign 'high' value (h)

Figure $7 a$

Figure $7 \mathrm{~b}$

\footnotetext{
${ }^{8}$ The power equilibrium could also be upset by shifts in the cost of expropriation, the nature of military technology - whether it favors defense or offense - and potential gain from cooperation.
} 
In the intermediate range between the two extremes (Figure 7) shifts in elite coordination can give rise to punctuated equilibria. Elites can coordinate behind the "good" threats they heed in one equilibrium while disregarding the "bad" ones in the other. When elites' collective interest is served by the ruler's threat as when it targets elite defection, the individual elites find it easy to assign high value for $\delta$ expecting that others also will. With the expected payoff of assigning a low value now relatively lower, the expected defiance ratio is also lower. That in turn makes the ruler's threat credible as the cost of carrying it out is now lower. By contrast, when faced with threats inimical to their interests, elites' expected defiance payoff exceeds that of compliance as each now assign a low value for $\delta$ expecting others will do so as well. That makes the threat inconsequential as the ruler expects it would be too costly to carry it out. ${ }^{9}$ In other words, in the case of "good" threats the individual elites expect $h>h$ * (and $\mathrm{h}<\mathrm{h}$ * in the case of "bad" ones) and coordinate accordingly. The Nash equilibrium is then at $\mathrm{h}=\mathrm{H}$ in the former case, and at $\mathrm{h}=0$ in the latter.

\section{II.2. Discussion}

The diagrams above are based on the simplifying assumption that individual elites are alike, i.e., homogenous units, which of course need not be the case. When some elites are more powerful than others or a small subset can coalesce to make themselves more powerful than the rest, the state can be captured by this dominant faction or coalition. This would suggest a transition from one state of the world characterized by dispersed power (depicted in Figure 7b) to another that is characterized by power consolidated by a faction (Figure 7a). Shifting economic and political conditions can bring about similar transitions, with or independently of shifts in the dominant faction at the helm. For instance, the late $17^{\text {th }}$ century trend towards bigger European states that had to "grow or die" in the face of intensified military competition (Parker 1996, Tilly 1992) imply a power shift in favor of the state (a move from Figure $7 b$ towards Figure 7a). But, at the same time, the increased dependence on revenue because of larger size of

\footnotetext{
${ }^{9}$ This also implies that the ruler is only powerful when it serves elite interests - or, using Greif's (2005) terminology, when it is "on the equilibrium path".
} 
armies and sophistication of weaponry suggests an increasing check on states' coercive power and, thus, a movement in the opposite direction. As North et al (2013) put it, the question states face is "whether to kill the goose that lays golden eggs and eat the goose today or pamper the goose and enjoy a flow of gold in the future" (p. 174). As increasingly who created and controlled wealth was not the "helpless peasant or powerless non-elite, but a strong and well-organized economic specialist" (p. 175) the cost of expropriation rose significantly higher during early modernity. That is why in their earlier work, North \& Weingast (1989) have argued that the advantage in power competition in this period shifted to states that honored economic rights and privileges which not only improved their borrowing terms but also fostered economic growth.

In their later work, they criticize this literature without disputing its facts for "assuming elements that were actually end products..." (p. 241). They now relate states' ability to make credible commitments first and foremost to the strength of intra-elite coalitions, for they argue that "the biggest threat to elite privileges is other elites" (p. 190). Credible commitments are hard to make under conditions of political strife and uncertainty since no ruler (or an elite faction) can but discount future revenue heavily when facing an existential threat. For future loss of revenue is a long run concern one can ill-afford when survival is at stake in the short-run. Only when elite privileges were converted into rights could they be permanently secured, and that along with the new right to form (perpetually lived) independent organizations "lower(ed) the costs of expanding the size of the coalition covered by these institutions" (p. 188). With "tools that allow(ed) elites to credibly commit to respecting fundamental elite rights" (p. 249) the result was states that could also credibly commit to respecting rights. The virtuous cycles comprising good governance, economic growth, military prowess, more growth and greater control over resources - along with their episodic collapse following wars and internal discord are all too common in human history in their view. Yet, what was unique is the more permanent anchoring of power balance in its intermediate range in the West with the evolution of political institutions after $18^{\text {th }}$ century (Figure 7 ), which they argue made it possible to permanently transform intra-elite relationships enabling the state and elites to constitute each other as they evolved together. In their view, the "rise of the West" was thus fundamentally 
about elites' ability to reduce their coordination costs by institutionalizing their coalitions (and the state) rather than a deal between them and the rulers who held coercive power.

\section{Conclusion}

In North and Weingast's later work with Wallis (North et al 2013) the modality of elite cohesion plays a crucial role on how the state interacts with the rest of society. Following on this approach the paper examines how elites can overcome their collective action problem through coordination. Their ability to institutionalize a cooperative bargain among themselves depends significantly on whether they can have the state function as a commitment device in enabling them to coordinate successfully, which in turn enables them to develop a collective reprisal threat to deter it from abuse of power. The basic insight holds that the credibility of the state's threats depends on the cost of carrying them out, which elites can have control over if they can act in tandem. Under certain states of the world, Elites can coordinate in being compliant when the ruler's threats serve their collective interest which raises the threats' credibility, while lowering that of those they dislike by their coordinated noncompliance making them costly to carry out. 
References:

Acemoglu, D. \& J. Robinson (2009). Economic Origins of Democracy and Dictatorship. Cambridge University Press.

Acemoglu, D. \& J. Robinson (2012). Why Nations Fail? The Origins of Power, Prosperity and Poverty. Crown Business.

Albertus, M. (2015). Autocracy and Redistribution: the Politics of Land Reform. Cambridge Un Press.

Albertus, M. \& V. Menaldo (2014). “Gaming Democracy: Elite Dominance During Transition and the Prospect of for Redistribution," British Journal of Political Science 44(3): 575-603.

Ansell, B. \& D. Samuels (2014). Inequality and Democratization: An Elite-Competition Approach. Cambridge Un Press.

Bates, R. (2001). Prosperity and Violence: The Political Economy of Development. New York: W.W. Norton \& Company.

Bates, R. (1983). Essays in the Political Economy of Rural Africa. New York: University of California Press.

Bates, R. (2008). When Things Fall Apart: State Failure in Late Century Africa. Cambridge University Press.

Bates, R., Greif, A., \& S. Singh (2002). “Organizing Violence," Journal of Conflict Resolutions 6(5): $599-628$.

Greif, A. (1994). "On the Political Foundations of the Late Medieval Commercial Revolution: Geneo During the Twelfth and Thirteenth Centuries," Journal of Economic History 54(4): 271-87.

Greif, A. (2005). "Commitment, Coercion, and Markets: The Nature and Dynamics of Institutions Supporting Exchange," in C. Menard \& M. Shirley (eds.) Handbook of New Institutional Economics. Springer.

Grossman, H. \& M. Kim (1995). "Swords of Ploughshares?" A Theory of the Security Claims to Property." Journal of Political Economy 103: 1275-1288.

Haber, S. (2006). “Authoritarian Government." In B. Weingast \& D. Whittman (eds.) Handbook Political Economy. Oxford Un Press. 
Hardin, R. (1995) One for All. Princeton. The Logic of Group Conflict. Princeton University Press.

Konrad, K. \& S. Skaperdas (2012). "The Market for Protection and the Origin of the State," Economic Theory 50(2): 417-443.

Mainwairing, S. (1999). Rethinking Party Systems in the Third Wave. Stanford Un Press.

Moselle, B. \& B. Polak (2001). "A Model of the Predatory State." Journal of Law and Economics and Organization 17(1): 1-13.

North, D. (1981). Structure and Change in Economic History. New York: Norton.

North, D. (1990). Institutions, Institutional Change and Economic Performance. Cambridge Un Press.

North, D. \& B. Weingast (1989). “Constitutions and Commitment: Evolution of Institutions Governing Public Choice," Journal of Economic History 49: 803:832.

North, D., Wallis, J. \& B. Weingast (2013). Violence and Social Orders. Cambridge University Press.

Olson, M. (1982). The Rise and Decline of Nations. Yale Un Press.

Olson, M. (1993). "Dictatorship, Democracy, and Development," American Political Science Review 87(3): 567-575.

Ostrom, E. (2003). "How Types of Goods and Property Rights Jointly Affect Collective Action," Journal of Theoretical Politics 15(3).

Skaperdas, S. (1992). "Cooperation, Conflict, and Power in the Absence of Property Rights," American Economic Review 82(4): 720-738.

Skaperdas, S. \& C. Sympoulos (2002). “Insecure Property Rights and the Stability of Exchange," Economic Journal 112: 133-146.

Smith, V. (1975)" The Economics of the Primitive Hunter Culture, Pleistocene Extinctions and the Rise of Agriculture," Journal Political Economy 83(4): 727-756.

Tilly, C. (1990). Coercion, Capital and European State. Blackwell Publishers.

Weingast, B. (1997). "The Political Foundations of Democracy and the Rule of Law," American Political Science Review 91(2). 
